\title{
PIM Kinase Inhibitor SGI-1776
}

National Cancer Institute

\section{Source}

National Cancer Institute. PIM Kinase Inhibitor SGI-1776. NCI Thesaurus. Code C82404.

A small-molecule pan-PIM protein kinase inhibitor with potential antineoplastic activity.

PIM kinase inhibitor SGI-1776 binds to and inhibits the activities of PIM-1, -2 and -3 serine/threonine kinases, which may result in the interruption of the G1/S phase cell cycle transition, the expression of pro-apoptotic Bcl2 proteins and tumor cell apoptosis. PIM kinases play key roles in cell cycle progression and apoptosis inhibition and may be overexpressed in various malignancies. 